Tasharruf: Journal Economics and Business of Islam Vol. 6, No. 1 (2021):20-30

Website: http://journal.iain-manado.ac.id/index.php/TJEBI/index

ISSN 2528-0325 (online) ISSN 2528-0317 (print)

\title{
TOURIST ATTRACTIONS AND SERVICESCAPE AS EFFORTS TO INCREASE VISITING INTEREST ON HALAL TOURISM IN BIMA CITY
}

\author{
Sri Ernawati \\ Sekolah Tinggi Ilmu Ekonomi Bima, NTB. \\ Jalan.Wolter Monginsidi Komplek Tolobali Kota Bima \\ sriernawati.stiebima.com \\ Ismunandar \\ Sekolah Tinggi Ilmu Ekonomi Bima, NTB. \\ Jalan.Wolter Monginsidi Komplek Tolobali Kota Bima \\ andar.stiebima@gmail.com
}

\begin{abstract}
Natural and cultural wealth is a potential asset for tourism in Indonesia. The combination of tourist attractions and supporting facilities is a special advantage for tourists. The purpose of this study was to determine and partially analyze the influence of tourist attractions as an effort to increase visiting interest and servicescape as an effort to increase visiting interest and simultaneously tourist attractions and servicescapes in increasing tourist interest in visiting the concept of halal tourism in Bima City. The number of samples is 100 respondents with purposive sampling through a questionnaire with a Likert scale. Collecting data using questionnaires, observation and literature study. Testing the data using SPSS (Statistical Package for the Social Sciences) version 20.0. Data analysis used multiple linear regression $t$ test, $F$ test are carried out. The results show that tourist attractions have an effect as an effort to increase interest in visiting and servicescape has an effect as an effort to increase interest in visiting and simultaneously tourist attractions and servicescape have an effect together as an effort to increase interest in visiting halal tourism in Bima City
\end{abstract}

Keywords: Tourist Attractions; Servicescape; Visiting Interest; Halal Tourism.

\begin{abstract}
ABSTRAK
Kekayaaan alam dan budaya menjadi aset potensi kepariwisataan di Indonesia. Kombinasi antara atraksi wisata dan fasilitas pendukung menjadi keunggulan tersediri yang istimewa bagi para wisatawan. Tujuan dari penelitian ini adalah untuk mengetahui dan menganalisis secara parsial pengaruh daya tarik wisata sebagai upaya peningkatan minat berkunjung dan servicescape sebagai upaya peningkatan minat berkunjung dan secara simultan daya tarik wisata dan servicescapes dalam meningkatkan minat berkunjung wisatawan berkonsep wisata halal di Kota Bima. Jumlah sampel dalam penelitian ini adalah 100 responden dengan teknik purposive sampling melalui kuesioner dengan skala likert. Pengumpulan data menggunakan kuesioner, observasi dan studi kepustakaan. Pengujian data menggunakan SPSS (Statistical Package for the Social Sciences) versi 20.0. Analisis data menggunakan regresi linear berganda, uji t, dan uji F. Hasil penelitian menunjukan bahwa Atraksi Wisata berpengaruh sebagai upaya meningkatkan Minat Berkunjung dan Servicescape berpengaruh berpengaruh sebagai upaya meningkatkan Minat Berkunjung dan secara simultan Atraksi Wisata dan Servicescape berpengaruh secara bersama sebagai upaya meningkatkan Minat Berkunjung pada wisata halal di Kota Bima
\end{abstract}

Kata Kunci: Atraksi Wisata; Servicescapa, Minat Berkunjung; Wisata Halal. 


\section{INTRODUCTION}

Tourism is one of the economic sectors that can improve the regional economy so that in turn it can improve the welfare of the community. The implementation of tourism activities cannot be separated from the resources owned and the involvement of stakeholders and other economic sectors to support the success of tourism development (Afriza \& Abadi, 2015).

The developments in the tourism sector can trigger the development of other sectors. It makes tourism a potential sector. One of them is the economic sector, through an increase in the number of destinations and tourism investment, which can increase employment. Currently, the trend in the world of tourism, there are changes in the motivation and consumption patterns of tourists (customer behavior patterns). Initially, it only focused on $3 \mathrm{~S}$ (sun, sea, and sand), turning to serenity, sustainability, and spirituality (Hermansyah, 2016). It shows that currently, the motivate for tourist trips carried out by tourists is not only to seek fresh air, enjoy natural beauty, but tourists also seek self-calm, sustainability, and spirituality.

A person's decision in determining the destination of a tourist destination has several factors that influence it, by knowing the factors that influence the decision to visit, the tour manager can plan for the right tourism development. The decision to visit tourists can be influenced by several factors, one of which is the attributes of tourism products. The attributes of tourism products are all facilities and infrastructure that tourists get since leaving their homes, arriving at tourist destinations, and returning home (Suwantoro, 2004). This is reinforced by research (Muflikhah et all., 2018) which states that tourist attractions have a significant effect on visiting decisions. This is also reinforced by (Malisti et al., 2019) that tourist attractions, amenities, and accessibility affect visiting decisions. At the Blue Banyu Natural Tourism Bath.

Servicescape is a means of delivering services from products or services through a service environment that is perceived by customers. The environment helps customers experience the services offered by the company. When customers feel comfortable service, it will be the company's advantage. Customers who are actively involved in experiencing the services of a product or service will be an added value to the company. (Dong Ping \& Noel Yee, 2013) explained that a good service environment from Servicescape will attract tourist participation in the products or services offered by the company. Other research related to servicescape was also conducted by (Lee \& Li, 2014), showing that there is a significant relationship between servicescape and restaurant visitor interest.

West Nusa Tenggara Province is one of Indonesia's mainstay areas for the development of world halal tourism. The area that has Mount Rinjani and Tambora is known to be good at 
developing Muslim friendly tourism. Besides, in 2019, NTB was named the best halal tourist destination in Indonesia, the Indonesian version of the Muslim Travel Index. This shows that NTB is indeed good at halal tourism. Besides, the number of visits to NTB has increased. Previously, it only grew two percent. Once you get the world's best halal award, it jumps sharply up to $32 \%$. Domestic tourists also jumped sharply, $47 \%$, "said Arief. He also explained that the number of tourists, both foreign and domestic, from year to year, continued to increase. Even in 2020, the number of tourists visiting NTB is targeted at 4.5 million people. NTB Governor, Dr. H. Zulkieflimansyah expressed his commitment to continue to develop halal tourism in NTB. Moreover, NTB has an exoticism and aura that is different from other regions in Indonesia, even the world. Islam is very compatible with travel. Moreover, halal tourism is currently the lifestyle of most of the world's people (Hernawardi, 2019)

Bima City is an autonomous city located in the eastern part of Sumbawa Island, West Nusa Tenggara Province. Seeing the tourism in Bima City is in line with what West Nusa Tenggara Province wants, namely to make NTB a Halal tourist destination, for that the Bima city government has made various breakthroughs to promote halal tourism such as the establishment of a floating mosque which is a halal tourism icon, proposing a budget of IDR 3.1 billion 2020 for the construction of a tourist dock, gazebo, glass buttom boat, water boom and other supporting access in the Kolo area which will be used as a culinary tourism area, Lawata beach as a tourist attraction in Bima embracing a cultural concept where stands that provide tourist needs are built with the concept of uma lengge (typical Bima house) and a modern concept where there is a family gathering place, teenagers to gather, the Japanese cave which is the legacy of the Japanese army when occupying Bima and water sports, there are mountainous areas such as the peak of Jatiwangi, puncu Nence, cultural areas such as Mesium Asi Mbojo, Tana Taraha (Makam Sultan Bima), natural attractions such as Ringi Ncangga Cave, So Numbe Beach, Ule Beach, Buata Tourism such as the Am Understood area which is integrated in Bima bay with Lawata Beach and Floating Mosque. Tourist objects in Bima City can become tourist attractions that increase the interest in visiting tourists.

Tourist attractions and Servicescape found in tourist destinations which are an attraction for people to come to visit a tourist destination. Choosing a tourist destination is important before making a tour. The uniqueness of a tourist spot and a comfortable environment with good facilities will be able to make tourists interested in visiting. Moreover, it is supported by adequate facilities and infrastructure, because tourist attractions will be able to provide a memorable experience that will make people reconsider visiting, but now there are very few 
halal tourist attractions that can provide this. That research wants to do research related to halal tourism. with the aim of this study to determine and partially analyze the influence of tourist attractions as an effort to increase interest in visiting and servicescape as an effort to increase interest in visiting and simultaneously tourist attractions and servicescape in increasing interest in visiting tourists with the concept of halal tourism in Bima City.

\section{LITERATURE REVIEW}

\section{Tourist Attractions}

Tourist attractions are said to a significant component in attracting tourists, attractions are the main capital (tourism resources) or a source of tourism. It can be concluded that a tourist attraction is everything that has beauty, which is valuable, whether in the form of diversity, which is unique, both in cultural wealth and man-made results which become a factor of attraction and become a destination for tourists to visit. makes tourists motivated to take tours to these tourist objects, (I Ketut suwena, 2010). According to (Middleton, 2001), five components must be present in tourist attractions in tourist destinations, namely: 1. Natural Attraction, 2. Built Attraction, 3.Cultural Attraction, 4. Social Attraction

\section{Servicescape}

Servicescape is anything that is physically present around the consumer during a service transaction meeting that can affect customer perceptions, both internally and externally. Physical facilities (servicescape) have several dimensions according to (Lovelock, christopher H, 2007) dimensions of servicescape, namely: 1. Ambient condition refers to environmental characteristics that can be felt by the five senses. 2. Spatial layout and functionality, is the floor plan, the size and shape of the furniture, as well as the potential equipment, and how it is arranged. 3. Signs, symbols, and artifacts which are objects in the service environment that act as explicit or implicit signals to communicate the company's image, help customers find what they are looking for, convey service scenarios.

\section{Visiting Interest}

Interest in visiting means potential consumers (visitors) who have and have never been and who are going to visit a tourist attraction. Interest is a driving force that causes a person to pay attention to an object. According to(Ferdinand, 2014), there are four indicators to measure repurchase interest, namely: a) Transactional interest is a person's tendency to buy a product. b) Exploratory interest Explorative interest describes the behavior of a person who is always looking for information about the product he is interested in and looking for information to 
support the positive properties of the product. c) Preferential interest is an interest that describes the behavior of someone who has a preference, especially in the product, this preference can change if it occurs with the product of the preference. d) Referential interest is someone's tendency to refer products to other people.

\section{Hypothesis}

H1: Tourist attractions affect efforts to increase interest in visiting halal tourism in Bima City

H2: Servicescape affect efforts to increase interest in visiting halal tourism in Bima City

H3: Tourist attractions and Servicescape affect efforts to increase interest in visiting halal tourism in Bima City

\section{RESEARCH METHOD}

This research uses a quantitative approach with a survey method. While this type of research is categorized as causal research. According to (Husein, 2014) causal design is used to measure the strong relationship and influence between independent variables (Tourist Attractions and Servicescape) on the dependent variable (Visiting Interest). The population determination is adjusted to the research needs, namely tourists who have visited Bima City. Sampling with purposive sampling technique where the determination of the sample is based on certain criteria that are tailored to the needs of the study as The characteristics of the respondents are that they have visited one of the tourist destinations in Bima City, are over 17 years old because they are considered able to answer the questionnaire statements and live in Bima City. The sample in this study amounted to 100 people with the research instrument using a questionnaire with a Likert scale. Data analysis using multiple linear regression, t-test, and ftest. To test the effect between variables using SPSS (Statistical Service Product Solutions) version 20.00 .

\section{RESULTS AND DISCUSSION}

Data collection with questionnaires was carried out online due to government policies requiring social distancing, distributing questionnaires to several whatsup groups of friends, family, alumni at school, students, so that respondents' answers could be obtained directly at the time of distributing the questionnaire. The general description of the respondents in this study can be seen from the characteristics of the respondents which include gender, age, and occupation in the field. 
Tasharruf: Journal Economics and Business of Islam Vol. 6, No. 1 (2021):20-30

Website: http://journal.iain-manado.ac.id/index.php/TJEBI/index

ISSN 2528-0325 (online) ISSN 2528-0317 (print)

Table 1. Respondent Data

\begin{tabular}{llcc}
\hline \multicolumn{1}{c}{ Characteristics } & \multicolumn{1}{c}{ Criteria } & $\begin{array}{c}\text { Number of } \\
\text { Respondents }\end{array}$ & Persentase \\
\hline Gender & a. Famale & 76 & 79 \\
& b. Male & 24 & 24 \\
Age & a. $17-25$ & 17 & 17 \\
& b. $26-35$ & 54 & 54 \\
Profession & c. $>35$ & 29 & 29 \\
& a. ASN (Civil state apparatus) & 24 & 24 \\
& b. Private employess & 27 & 27 \\
& c. Enterpreneur & 12 & 12 \\
& d. House Wife & 8 & 8 \\
& e. College studen & 29 & 29 \\
\hline
\end{tabular}

$\mathrm{n}=100$

From the data above, it can be seen that the number of respondents is as much as 100 people, which shows that from the gender criteria the largest acquisition is from famale by $76 \%$. From the data above, it can be seen that the number of respondents is as much as 100 people, which shows that from the gender criteria the largest acquisition is from women by $76 \%$. From the age range of $26-35$ years, the most is $54 \%$ and the job criteria of students are $29 \%$.

In this study, using multiple linear regression analysis with the help of the SPSS 20.00 for Windows program to determine the effect of tourist attraction variables (X1) and Servicescape (X2) on visiting interest (Y). The results of multiple linear regression tests in this study can be seen in the following table:

Table 2. Multiple Linear Regression Test Results

Coefficients ${ }^{\mathrm{a}}$

\begin{tabular}{|c|c|c|c|c|c|c|}
\hline \multicolumn{2}{|c|}{ Model } & \multicolumn{2}{|c|}{$\begin{array}{l}\text { Unstandardized } \\
\text { Coefficients }\end{array}$} & \multirow{2}{*}{$\begin{array}{l}\text { Standardized } \\
\text { Coefficients } \\
\text { Beta }\end{array}$} & \multirow[t]{2}{*}{$\mathrm{t}$} & \multirow[t]{2}{*}{ Sig. } \\
\hline & & B & Std. Error & & & \\
\hline & (Constant) & 19.930 & 3.900 & & 5.111 & .000 \\
\hline \multirow[t]{2}{*}{1} & Tourist Attractions & .260 & .084 & .291 & 3.084 & .003 \\
\hline & Servcescape & .183 & .080 & .217 & 2.298 & .024 \\
\hline
\end{tabular}

a. Dependent Variable: Visiting Interest

Source: primary data processed by SPSS v. 20, 2020

From the results of the regression analysis, it can be seen that the simple linear regression equation is as follows: $\mathrm{Y}=19.930+0.260 \mathrm{X} 1+0.183 \mathrm{X} 2$. Based on this equation, it can be explain as follows: 
a. A constant value of 19,930 can be interpreted that if the Tourism Attraction (X1) and Servicescape (X2) variables are considered zero, then Visiting Interest (Y) will be 19,930.

b. The beta coefficient value on the tourist attraction variable (X1) is 0.260 , meaning that every change in the tourist attraction variable (X1) is one unit, which will result in a change in visiting interest $(\mathrm{Y})$ of 0.260 units, with other assumptions that are fixs.

c. The beta coefficient value on the Servicescape variable (X2) is 0.183 , which means that every change in the Servicescape variable (X2) by one unit will result in a change in Visiting Interest $(\mathrm{Y})$ of 0.183 units, with other assumptions being fixed

Furthermore, to find out whether tourist attractions (X1), Servicescape (X2) affect visiting interest $(\mathrm{Y})$, testing is done using the t-test. The test results can be explained as follows:

Table 3. Parcial Test Results (t-test)

\section{Coefficients $^{\mathrm{a}}$}

\begin{tabular}{lllllll}
\hline Model & & \multicolumn{2}{l}{$\begin{array}{l}\text { Unstandardized } \\
\text { Coefficients }\end{array}$} & $\begin{array}{l}\text { Standardized } \\
\text { Coefficients }\end{array}$ & $\mathrm{t}$ & Sig. \\
& $\mathrm{B}$ & Std. Error & Beta & & \\
\hline & & & & & & \\
\hline & (Constant) & 19.930 & 3.900 & & 5.111 & .000 \\
$1 \quad$ & Tourist Attractions & .260 & .084 & .291 & 3.084 & .003 \\
& Servicescape & .183 & .080 & .217 & 2.298 & .024 \\
\hline
\end{tabular}

a. Dependent Variable: Visiting Interest

Source: primary data processed by SPSS v. 20, 2020

H1: Tourist attractions are influential as an effort to increase Visiting Interest in Halal Tourism in Bima City

The statistical results of the t-test for the tourist attraction variable obtained a $\mathrm{t}$-count value of 3.084 with a t-table value of $1.984(3.084>1.66039)$ with a significance value of 0.003 less than $0.05(0.003<0.05)$, so it can be stated that "Attraction Tourism is influential as an effort to increase Visiting Interest in Halal tourism in Bima City "Proven" This is following the results of research by (Mauludin, 2017)showing that there is a significant influence between Tourist Attractions (X) on Visiting Interest (Y) Tourists to Attraction Tourism of Darma Reservoir Kuningan Regency and research by (Muharromah\& Anwar, 2020) states that it shows that tourist attraction variables have a positive and significant effect on the decision to visit the Religious Tourism Object of the Tomb of KH. Abdurrahman Wahid.

H2: Servicescape is influential as an effort to increase Visiting Interest in Halal Tourism in Bima City 
The statistical results of the t-test for the Servicescape variable obtained a t-count value of 2.298 with a t-table value of $1.984(2.298>1.66039)$ with a significance value of 0.024 less than $0.05(0.024>0.05)$, so it can be stated that "Servicescape affects. as an effort to increase Visiting Interest in halal tourism in Bima City "Proven" This is following the results of research by(Nurochani \& Mulyana, 2017) which states that Servicescape partially influences purchasing decisions (Studies at the "Bunga Mawarni" Maternity Clinic, Banjar City) and research results (Tatangin, et all, 2017) which states that Servicescape has a significant effect on customer satisfaction at the Mie Medan 99 Manado Restaurant and (Putra, 2017) research which states that Servicescape has a significant positive effect given the servicescape variable on the interest in returning tourists to the tourist attractions of Jawa Timur Park 2 Kota. Stone. Of the three factors forming the servicescape, the one that was assessed positively and the highest by visitors was the atmosphere factor. Visitors get a supportive atmosphere when visiting Jawa Timur Park 2 Batu City

The F-test is used to determine whether the independent variables together (simultaneously) have a significant positive or negative influence on the dependent variable. The results of the F-test can be seen in the following table:

Table 4. Simultah Test Results (Test F)

ANOVA ${ }^{\mathrm{a}}$

\begin{tabular}{lllllll}
\hline Model & & Sum of Squares & df & Mean Square & F & Sig. \\
\hline & Regression & 346.214 & 2 & 173.107 & 8.197 & $.001^{\mathrm{b}}$ \\
1 & Residual & 2048.536 & 97 & 21.119 & & \\
& Total & 2394.750 & 99 & & & \\
& & & & & &
\end{tabular}

a. Dependent Variable: Visiting Interest

b. Predictors: (Constant), Servicescape, Tourist Attractions

Source: primary data processed by SPSS v. 20, 2020

H3: Tourist Attractions and Servicescape are influential as an effort to increase Visiting Interest in Halal Tourism in Bima City

The results of the F test statistics for the Tourism Attraction variable (X1), Servicescape (X2) obtained an F-count value of 8,197 with a Ftable value of 3.09 (8,197 >3.09) with a significance value of 0.001 less than $0.05(0.01) .<0.05)$, then the hypothesis H3 which states that Tourist Attractions (X1), Servicescape (X2) have an effect on Visiting Interest (Y) on halal tourism in Bima City "Proven". 


\section{Tourist Attractions are Influential as an Effort to Increase Visiting Interest in Halal}

\section{Tourism in Bima City}

One of the important factors that can influence the interest of tourists to visit a tourist attraction is the existence of tourist attractions. Less diverse tourist attractions tend to make tourists less interested in visiting tourist objects because tourist attractions are closely related to the sustainability of a tourist area. So that we need innovation or new ideas that can attract tourists to visit. By continuing to carry out innovations towards tourist objects in Bima City, it is hoped that it can increase the interest in visiting tourists to Bima City, especially since Bima City is a strategic area with an area position in the middle that can connect the western and eastern regions. Tourism products and services, as well as tourist destinations in halal tourism, are the same as general tourism. As has been done by the city government of Bim, where each tourist attraction is provided a prayer room for worship and serving halal culinary tours. With the concept of Halal tourism, it is expected that an increase in the number of tourists visiting Bima City.

\section{Servicescape is Influential as an Effort to Increase Visiting Interest in Halal Tourism in}

\section{Bima City}

Servicescape in terms of spatial layout/location where the shape or design of halal tourism objects in Bima City affects the interest in visiting tourists because of its strategic location and placement of tourist objects in the middle of the city so that they can be reached by tourism with a distance of 20 minutes to 1 hour which is supported with smooth transportation. The real thing that can be seen and felt is the physical environment (servicescape) where service providers and services are located. Many of these are found in the city of Bima which provides halal culinary tours for both young people and family gatherings. All the facilities available at the tourist attraction can provide adequate comfort and environment so that it is comfortable to relieve fatigue and refreshing.

\section{Tourist Attractions and Servicescape are Influential as an Effort to Increase Visiting Interest in Halal Tourism in Bima City}

Tourist destination managers are competing with each other to increase the number of tourist visits. Increasing tourist visits is built on the creation of tourist satisfaction from tourist attractions that exist in a tourist attraction. The facilities provided by tourist objects in Bima City are everything that is deliberately provided by service providers to be used and enjoyed by consumers to provide a maximum level of satisfaction. So from this research proves that tourist attractions and servicescape in halal tourism in Bima City are two determining factors for 
increasing tourist interest in visiting tourists, those who want a unique tourist attraction supported by adequate facilities generate interest to visit, especially after enjoying so that a sense of satisfaction arises., then it is certain that the tour will make a repeat visit to the halal tourism object in Bima City

\section{CONCLUSION}

Tourist Attractions and Servicescape are influential as an effort to increase Visiting Interest in halal tourism in Bima City both partially and simultaneously. This can be seen from the calculated $t$ value which is greater than the $t$ table value, as well as the calculated $f$ value is greater than the calculated $\mathrm{f}$ value. Suggestions that can be conveyed in this research are the City Government of Bima as the party that regulates and controls all the wealth in the City of Bima, including the existing tourist objects, must play an active role by stimulating pokdarwis (tourism-conscious people) to synergize with each other in making halal tourism a concept for tourism development. sustainable.

\section{REFERENCES}

Afriza, L., \& Abadi, H. (2015). Pengaruh Atraksi Pariwisata Terhadap Pemberdayaan Masyarakat Di Pantai Cimaja Cikakak Sukabumi. Tourism Scientific Journal, 1(1), 85. https://doi.org/10.32659/tsj.v1i1.6

Dong, P. \& Noel. Y.-M. S. (2013). Servicescape Element, Customer Predispositions and Service Experience: The Case of Theme Park Visitors. Journal of Tourism Management, 36, 541551.

Ferdinand, A. tae(universitas diponegoro). (2014). Metode penelitian manajemen (3 (ed.)). Semarang : Badan penerbit Universitas Diponegoro.

Hermansyah. (2016). Potensi besar wisata religi. http://koran-sindo.com/page/news/2016-05$29 / 0 / 0$

Hernawardi. (2019). pariwisata halal dunia kunjungan wisatawan halal di NTB meningkat. https://www.gatra.com/detail/news/450453/ekonomi/pariwisata-halal-dunia-kunjunganwisatawan-di-ntb-meningkat

Husein, U. (2014). Metode Penelitian untuk skripsi dan tesis Bisnis. Jakarta:PT raja Grafindo Persada.

I Ketut suwena, I. G. N. W. (2010). Pengetahuan dasar ilmu pariwisata (1 (ed.)). Udayana University Press.

Lee, L.-Y., \& Li, L.-Y. (2014). Effects of Servicescape, Waiting Motivation and Conformity on Time Perception and Behavioral Intentions. International Journal of Marketing Studies, 6(4), 83-91. https://doi.org/10.5539/ijms.v6n4p83 
Lovelock, christopher H, L. K. W. (2007). manajemen pemasaran jasa. jakarta : Indeks.

Malisti, R. F., Wahyudi, P., \& Hastari, S. (2019). Pengaruh Atribut Produk Wisata Terhadap Keputusan Berkunjung Pada Pemandian Wisata Alam Banyubiru. Jurnal EMA, 4(1), 2329. https://doi.org/10.47335/ema.v4i1.35

Mauludin, R. (2017). Pengaruh Atraksi Wisata Terhadap Minat Berkunjung Wisatawan Ke Daya Tarik Wisata Waduk Darma Kabupaten Kuningan. Jurnal Manajemen Resort Dan Leisure, 14(2), 57-68. https://doi.org/10.17509/jurel.v14i2.9241

Middleton. (2001). marketing in travel and tourism. London : Butterworth Heinemann.

Muflikhah Vegita., Yustisia Pasfatima Mbulu., I. M. A. (2018). Pengaruh Electronic Word Of Mouth Di Media Sosial Instagram Dan Atribut Produk Wisata Terhadap Keputusan Berkunjung Di Floating Market Lembang. Journal of Tourims Destination and Atraction, 6(2), 16-29. http://journal.univpancasila.ac.id/index.php/jtda/article/view/770

Muharromah Gabriele Lailatul, M. K. A. (2020). Pengaruh Atraksi Wisata, Amenitas Dan Aksesibilitas Terhadap Keputusan Berkunjung Pada Objek Wisata Religi Makam Kh. Abdurrahman Wahid. Ekonomika Dan Bisnis Islam, 3(2), 152-164. https://journal.unesa.ac.id/index.php/jei/article/view/9086

Nurochani, N., \& Mulyana, D. (2017). Pengaruh Servicescape Dan Citra Merek Terhadap Keputusan Pembelian (Studi pada Klinik Bersalin Bunga Mawarni Kota Banjar). Jurnal Manajemen Pemasaran, 11(1), 10-15. https://doi.org/10.9744/pemasaran.11.1.11-15

Putra, Y. D. P. (2017). Pengaruh Servicescape, Costomer Predispot]sition, And Destination, Attractiveness On People Intention to Revisit Jatim Mpark 2 Kota Batu. Jurnal Ilmiah Mahasiswa FEB, 5(2). https://jimfeb.ub.ac.id/index.php/jimfeb/article/view/4056

Suwantoro, G. (2004). Dasar-Dasar Pariwisata. Yogyakarta : ANDI.

Tatangin, Andre Eris., Imelda W.J. Ogi., S. S. R. L. (2017). Pengaruh Servicescape Dan Kualitas Produk Terhadap Kepuasan Pelanggan Pada Rumah Makan Mie Medan 99 Manado. Jurnal Emba: Jurnal Riset Ekonomi, Manajemen, Bisnis Dan Akuntansi, 5(2), 811-820. https://ejournal.unsrat.ac.id/index.php/emba/article/view/15996 